\title{
On the occurrence of Persian Gulf Sea Snake, Hydrophis lapemoides (Gray, 1849) (Reptilia, Squamata, Elapidae, Hydrophiinae), along the coast of Bangladesh
}

\author{
Mohammad Abdul Wahed Chowdhury ${ }^{1,2}$, Md. Rafiqul Islam ${ }^{1,2}$, Abdul Auawal $^{1}$, Harij Uddin ${ }^{2}$, \\ Najmul Hasan ${ }^{2}$, Ibrahim Khalil Al Haidar ${ }^{1,3 *}$ \\ 1 Venom Research Centre, Chittagong Medical College, Chattogram 4203, Bangladesh • MAWC: wahed.chowdhury@cu.ac.bd (D https://orcid. \\ org/0000-0003-2893-0026 • MRI: rafiqislamw@gmail.com (D https://orcid.org/0000-0002-5645-8454 • AA: aauawal@gmail.com • IKAH: \\ ibrahimalhaidar88@gmail.com @ https://orcid.org/0000-0002-1011-0882 \\ 2 Department of Zoology, University of Chittagong, Chattogram 4331, Bangladesh •HU: harijuddin11@gmail.com•NH: najmulcu1998@gmail. \\ com \\ 3 Department of Biochemistry and Molecular Biology, University of Chittagong, Chattogram 4331, Bangladesh • ibrahimalhaidar88@gmail.com \\ (D) https://orcid.org/0000-0002-1011-0882 \\ * Corresponding author
}

\begin{abstract}
We provide the first evidence of the presence of the Persian Gulf Sea Snake, Hydrophis lapemoides (Gray, 1849), along the coast of Bangladesh. This species was assumed to exist in there, but neither specimens nor confirmed observations exist until now. We document here the first confirmed record of H. lapemoides based on a freshly collected and taxonomically verified specimen from coastal Bangladesh. The Bangladeshi specimen had the following diagnostic characters: 55 black bands, a dorsal scale composition of 35:51:43, 342 ventrals, one pre-ocular, two post-oculars, $2+3$ temporals, 8 supralabials (II largest and contact prefrontals; III-IV contact orbit) and 8 infralabials (I-IV contact genials).
\end{abstract}

Keywords

Distribution, extent of occurrence, geographic range, morphology, new country record

Academic editor: Abhijeet Bayani | Received 12 March 2021 | Accepted 12 July 2021 | Published 26 July 2021

Citation: Chowdhury MAW, Islam MR, Auawal A, Uddin H, Hasan N, Haidar IKA (2021) On the occurrence of Persian Gulf Sea Snake, Hydrophis lapemoides (Gray, 1849) (Reptilia, Squamata, Elapidae, Hydrophiinae), along the coast of Bangladesh. Check List 17 (4): 1075-1080. https://doi. org/10.15560/17.4.1075

\section{Introduction}

Sea snakes are secondarily adapted marine reptiles occurring in the shallow, coastal waters throughout tropical and subtropical regions (De Silva 1994; Rasmussen 1997; Heatwole 1999; Sanders et al. 2008). There are
3,889 species of snakes in the world (Uetz and Hallermann 2021), of which only 72 species are adapted to the marine life (Murphy 2012; Ukuwela et al. 2012; Nankivell et al. 2020). Bangladesh is a South Asian country in 
the delta of the Bay of Bengal, where 102 snake species have been reported until now (Husain 1977; Montaquim et al. 1980; Khan 1982, 1987, 1992, 2015, 2018; Sarker and Sarker 1985, 1988; Ahsan 1998; Asmat and Hannan 2007; Mahony and Reza 2008; Kabir et al. 2009; Mahony et al. 2009; Ahsan et al. 2015; IUCN Bangladesh 2015; Haidar et al. 2020; Romon et al. in press). So far, 16 species of sea snakes from Bangladesh have been included in the Red List of the International Union for Conservation of Nature (IUCN Bangladesh 2015). Among these species, the occurrence of 11 are substantiated in the scientific literature (Khan 1982, 1987, 1992, 2008, 2015, 2018; Sarker and Sarker 1988; Kabir et al. 2009; Hasan et al. 2014; Sarker et al. 2017). However, presence of five species-Hydrophis lapemoides (Gray, 1849), H. obscurus Daudin, 1803, H. stokesii (Gray, 1846), Laticauda colubrina (Stejneger, 1907), and L. laticaudata (Linnaeus, 1758) - is yet to be confirmed.

Among these five species, $H$. lapemoides was reported from Bay of Bengal at Puri (Odisha, India), and two of its subjective junior synonyms, Hydrophis stewartii Anderson, 1872 and Hydrophis dayanus Stoliczka, 1872, have their type localities on the coast of Odisha (India) and Myanmar, respectively (Smith 1943; Ganesh et al. 2019). Hydrophis lapemoides is known to be distributed along the coasts of Oman, United Arab Emirates, Qatar, Bahrain, Saudi Arabia, Kuwait, Iraq, Iran, Pakistan, India, Sri Lanka, Myanmar, Thailand, Malaysia, and Singapore (Fig. 1; Ahamed 1975; Rasmussen 1987; Somaweera and Somaweera 2009; Rasmussen et al. 2010; Wallach et al. 2014; Buzás et al. 2018), which implies that it should be present in Bangladesh as well. However, specific records of $H$. lapemoides from
Bangladesh coast were lacking. Here, we report the first confirmed presence of this species in Bangladesh based on morphological and morphometric study of a recently collected specimen.

\section{Methods}

The snake specimen was procured from a local fish market of Chittagong University campus on 2 January 2021 as a routine snake rescue by the Venom Research Centre, Bangladesh. The snake was caught as by-catch during fishing and unintentionally handed over to fish seller. The individual was still alive but weak and showing passive behavior during collection and died within 4 hours of procurement. The dead specimen was tagged and preserved in $70 \%$ ethanol following the Dead Snake Preservation Protocol v. 2.1 of the Venom Research Centre. We resurveyed the fishing area (Foillatoli, Chattogram) along the coast of Bay of Bengal with help of fishermen to obtain plausible GPS coordinates for the catch.

To identify the snake, morphological and meristic data were taken and compared with the standard literature (Volsøe 1939; Smith 1943; Ahamed 1975; Rasmussen 1987, 1993; Das 2010; Rezaie-Atagholipour et al. 2016; Ganesh et al. 2019). A lamp with simple microscope $(5 \times)$, standard measuring tape, a Vernier scale (to the nearest $0.1 \mathrm{~cm}$ ), a digital weighing balance (to the nearest $0.01 \mathrm{~g}$ ), and a sexing probe were used to obtain morphological and meristic data. The specimen was photographed using a Canon 600D camera.

The specimens is deposited in the collection of Venom Research Centre, Bangladesh (BAP-H1-001).

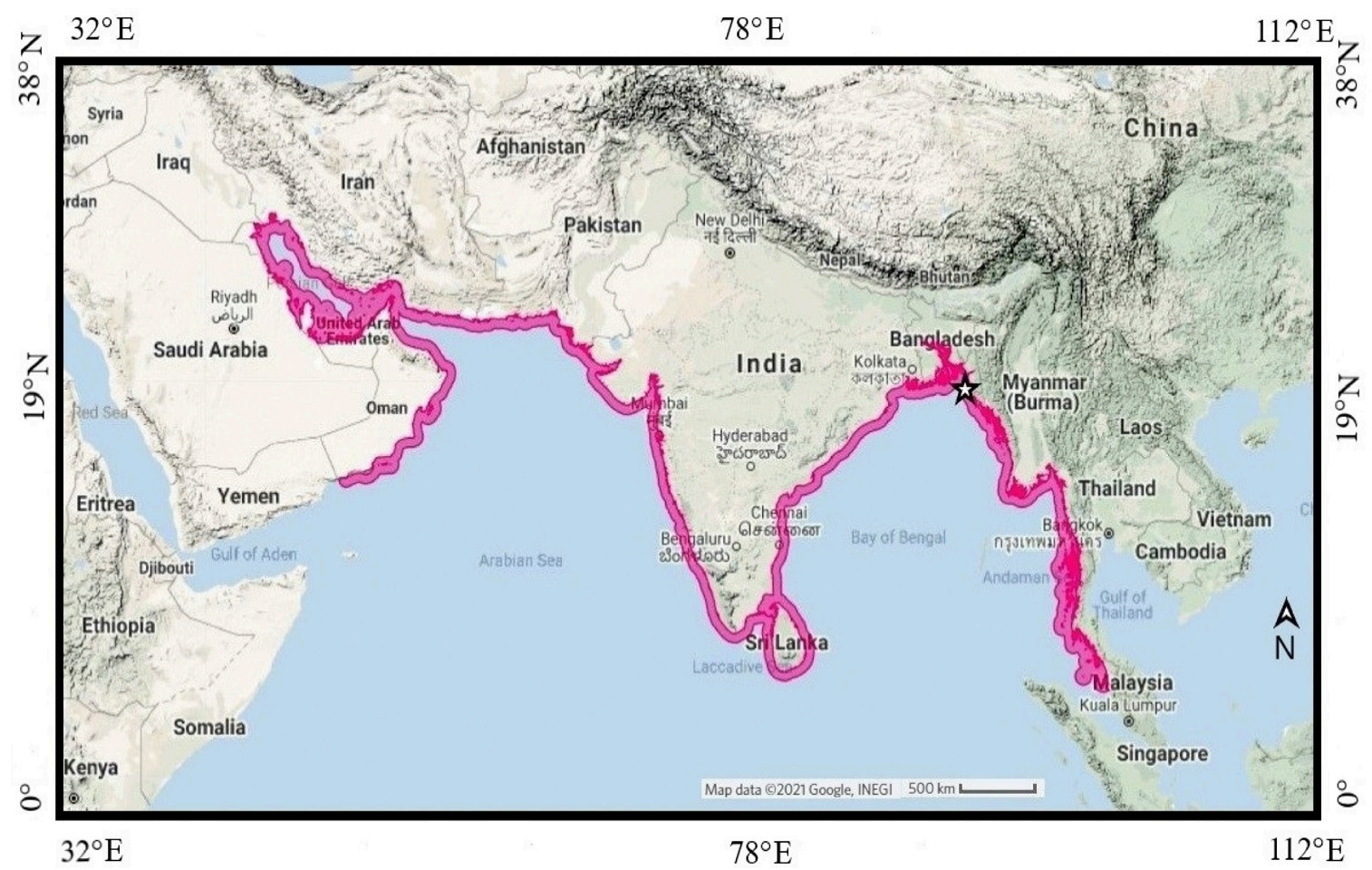

Figure 1. Distribution range of Hydrophis lapemoides from the Persian Gulf to the Malacca Straits. Black star icon depicts the location of current record from Chattogram of Bangladesh (map source: 02021 Google, INEGI). 


\section{Results}

Class Reptilia

Order Squamata

Family Elapidae

Genus Hydrophis Latreille, 1801

\section{Hydrophis lapemoides (Gray, 1849)}

Figures 1, 2

New record. Bangladesh - Chattogram - Foillatoli; 22 ${ }^{\circ} 19^{\prime} 41^{\prime \prime} \mathrm{N}, 091^{\circ} 45^{\prime} 14^{\prime \prime} \mathrm{E}$; 0 m alt.; 02.I.2021; Mohammad Abdul Wahed Chowdhury, Harij Uddin \& Najmul Hasan leg.; shore of the Bay of Bengal; 1, SVL $36.3 \mathrm{~cm}$, TL $4.3 \mathrm{~cm}$, weight $32.3 \mathrm{gm}$, BAP-Hl-001.

Description. The specimen is characterized by $35: 51: 43$ rows of dorsal scales. It has 342 small, rectangular
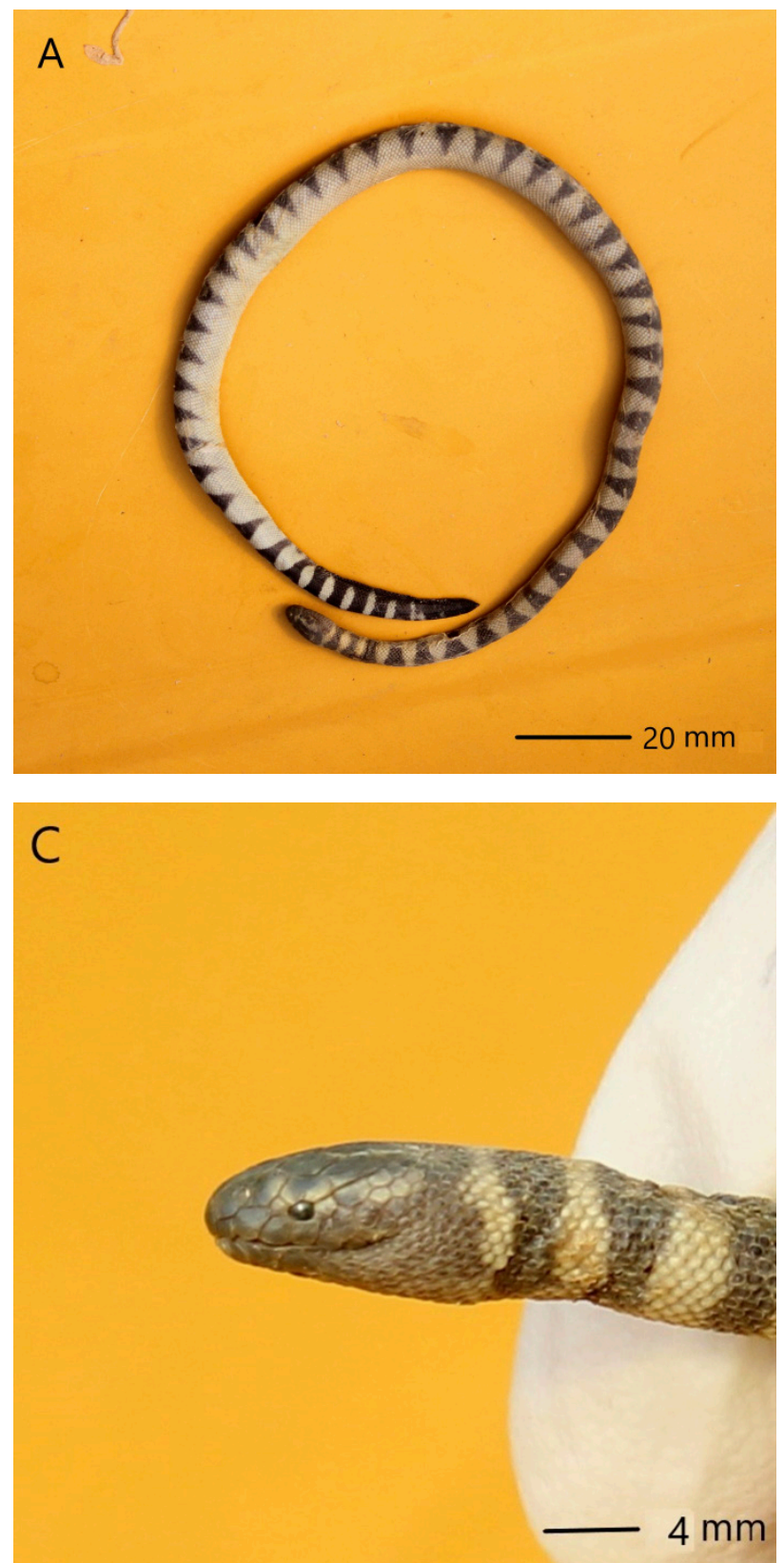

ventral scales, and the preanal plate is shielded with four small scales (Fig. 2D). The dorsal side of the head shows a large hexagonal frontal, a single pre-ocular, a pair of post-oculars, and $2+3$ temporals (Fig. 2C). The snake also has eight supralabials; $2^{\text {nd }}$ supralabial largest and touching pre-frontal, $3^{\text {rd }}$ and $4^{\text {th }}$ touching eye; the subocular scale absent. The lower jaw is characterized with two pairs of chin shields and eight infralabials; $1^{\text {st }}$ to $4^{\text {th }}$ touching chin shields and $1^{\text {st }}$ separates chin shields from mental. The snake has a robust body, a grey dorsum with black bands, a small indistinct head, dorsally positioned nasals, small round eyes with black pupil, and a laterally flattened tail (Fig. 2A). The small, indistinct head is dark, with curved white marks from forehead to back of the head along the eyes (Fig. 2B). There are 49 black bands along the body narrowing towards flanks and absent on ventral side. The tail possesses six dark bands,
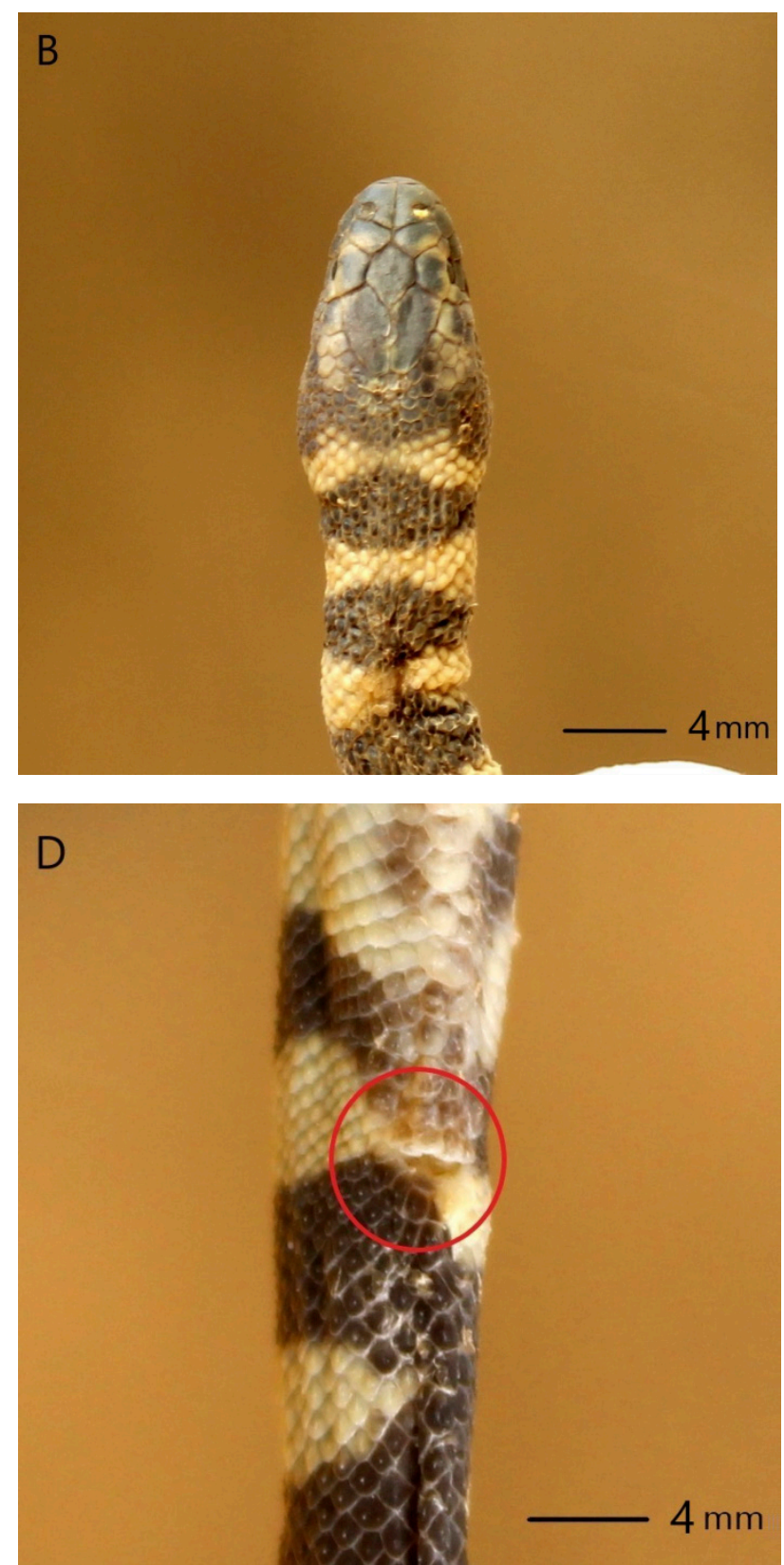

Figure 2. Hydrophis lapemoides (BAP-HI-001, SVL $36.3 \mathrm{~cm}$, TL $4.3 \mathrm{~cm}$ ). A. Photograph of the preserved specimen. B. Dorsal view of head. C. Lateral view of head. D. Anal aperture (photographs: Ibrahim K.A. Haidar). 
wider near the dorsum, narrower along the lateral side, becoming much broader at the subcaudal region touching each other while the last band covers entire tail tip.

Our evaluation of meristic characteristics verified the specimen as $H$. lapemoides (Table 1).

The morphological characters of the collected specimen were compared with other elapid sea snakes of the Indian Ocean, including the Andaman Sea, Bay of Bengal, Laccadive Sea, and Gulf of Thailand. Presence of much reduced ventral scales and dorsally positioned nostrils in the specimen excludes the genus Laticauda (vs. large ventrals and laterally positioned nostrils). The composition of dorsal scale rows $(n=51)$ along midbody of our specimen distinguish it from Aipysurus eydouxii (vs. 17), H. aagaardi (vs. 39-47), H. anomalus (vs. 33), H. atriceps (vs. 39-49), H. belcheri (vs. 32-36), H. brookii (vs. 37-45), H. cantoris (vs. 41-48), H. curtus (vs. 25-43), H. cyanocinctus (vs. 37-47), H. gracilis (vs. 29-43), H. inornatus (vs. 43-44), H. jerdoni (vs. 19-21), H. klossi (vs. 31-39), H. mamillaris (vs. 35-43), H. melanosoma (vs. 35-45), H. nigrocinctus (vs. 39-45), H. obscurus (vs. 29-37), H. pachycercos (vs. 39-45), H. peronii (vs. 23-31), H. perviceps (vs. 19), H. sibauensis (vs. 35-37), H. spiralis (vs. 33-38), H. torquatus (vs. 35-42), and Kolpophis annandalei (vs. 70-100). The specimen possesses small rectangular ventrals $(n=342)$, which are less than the counts of $H$. fasciatus (vs. 410 445) and H. stricticollis (vs. 374-452), and more than the counts of $H$. bituberculatus (vs. 247-290), H. lamberti (vs. 258-306), H. ornatus (vs. 209-312), H. schistosus (vs. 239-322), H. stokesii (vs. 226-286), and H. viperinus (vs. 226-274). The presence of a complete preanal in our specimen differentiates it from $H$. caerulescens (vs. divided preanal). Apparently a black dorsum and yellow ventrum is a distinct body coloration of $H$. platurus. Additionally, H. lapemoides is distinguished from its close congener $H$. cyanocinctus by the number of dorsal scales at midbody (51 vs. 37-47), contact of the supralabials with eye (III-IV vs III-V), scale patterns on the thickest part of body (feebly imbricate vs. imbticate), and shape of frontal scale (hexagonal vs. longer than broad).

\section{Discussion}

The range of Hydrophis lapemoides extends from the Persian Gulf to the Strait of Malacca along the coast of the Arabian Sea, Laccadive Sea, Bay of Bengal, Andaman Sea, and Gulf of Thailand (Smith 1943; Das 2010). Although, Bangladesh lies within the geographic range of $H$. lapemoides, the presence of the species in Bangladesh waters was doubtful due to the absence of any specimens. Our new record, therefore, is the first evidence of $H$. lapemoides in Bangladesh waters.

This species was assessed as Data Deficient in Bangladesh (IUCN Bangladesh 2015), and an earlier assessment by Rasmussen et al. (2010) considered this species to be Least Concern globally. Like other sea snakes, $H$. lapemoides is facing threats such as capture in by-catch and intentional killing by fishermen, habitat degradation, exploitation as food, and movement of heavy trawls suffocating habitat (Ward 2000; Wassenberg et al. 2001; Milton et al. 2009; Rasmussen et al. 2010; Das 2012; Sarker 2013; Ganesh et al. 2019). With this in mind, additional information on its habitat, ecology, and threats to aid in the conservation of $H$. lapemoides.

\section{Acknowledgements}

We gratefully acknowledge kind support of Dr. Aniruddha Ghose, Dr. Abudullah Abu Sayeed (Chittagong Medical College, Chattogram). We received financial support from the Venom Research Centre, Bangladesh, which affiliated with Non-Communicable Disease Control program of the Directorate General of Health Services, Ministry of Health and Family Welfare, Government of the People's Republic of Bangladesh during this study [grant reference DGHS/LD/NCDC/Proc. Plan/RPA-GOB (Service)/2019-2020/SP-03/Negotiation/1654].

\section{Authors' Contributions}

Conceptualization: MAWC, IKAH. Formal analysis: MAWC, MRI, AA, IKAH. Data curation: MRI, NH, HU, IKAH. Visualization: IKAH.

Table 1. Comparative accounts on the meristic characteristics of the present specimen and previous descriptions of Hydrophis lapemoides.

\begin{tabular}{lcc}
\hline Characteristics & This study & Previous studies* \\
\hline Number of bands & 55 (49 on body, 6 on tail) & $29-64$ \\
Dorsal scales on the neck & 35 & $29-35$ \\
Dorsal scales on the mid-body & 51 & $40-57$ \\
Ventrals & 342 & $288-404$ \\
Pre- 0 cular & 1 & 1 \\
Post- 0 culars & 2 & $2 / 3$ \\
Temporals & $2+3$ & $2+3 / 3+3$ \\
Supralabials & 8 (II largest and contact prefrontal; III-IV contact orbit) \\
Infralabials & 8 (I-IV contact genials) & 8 (II contact prefrontal; III-IV/III-V contact orbit) \\
Preanal & Shielded with four small scales & 8 (I-II/I-IV contact genials) \\
Scales on thickest part of body & Shielded with four small scales
\end{tabular}

*Data compiled from Volsøe 1939; Smith 1943; Ahamed 1975; Rasmussen 1987, 1993; Das 2010; Rezaie-Atagholipour et al. 2016; Ganesh et al. 2019. 


\section{References}

Ahamed S (1975) Sea snakes of the Indian Ocean in the collection of the Zoological Survey of India together with remarks on the geographical distribution of all Indian ocean species. Journal of the Marine Biological Association of India 17 (1): 73-81.

Ahsan MF (1998) Country reports for Bangladesh—herpetofauna of Bangladesh: present status, distribution and conservation. In: Biology and conservation of the amphibians, reptiles and their habitats in South Asia. Proceedings of the International Conference on the Biology and Conservation of the Amphibians and Reptiles of the South Asia, Sri Lanka, 9-17.

Ahsan MF, Haidar IKA, Rahman MM (2015) Status and diversity of snakes (Reptilia: Squamata: Serpentes) at the Chittagong University Campus in Chittagong, Bangladesh. Journal of Threatened Taxa 7 (14): 8159-8166. https://doi.org/10.11609/ jott.2431.7.14.8159-8166

Asmat GSM, Hannan MA (2007) Checklist of wild animals of Bangladesh. Gazi Publishers, Dhaka, Bangladesh, 292 pp.

Buzás B, Farkas B, Gulyás E, Géczy C (2018) The sea snakes (Elapidae: Hydrophiinae) of Fujairah. Tribulus 26: 4-31.

Das I (2010) A field guide to the reptiles of South-East Asia. Bloomsbury Publishing, London, UK, 376 pp.

Das CS (2012) Declining snake population — why and how: a case study in the mangrove swamps of Sundarban, India. European Journal of Wildlife Research 59 (2): 227-235. https://doi.org/ 10.1007/s10344-012-0669-4

De Silva A (1994) An account of the sea snakes (Serpentes: Hydrophiidae) of Sri Lanka. In: Gopalakrishnekone P (Ed.) Sea Snake Toxinology. Singapore University Press, Singapore, 234-249.

Ganesh SR, Nandhini T, Samuel VD, Sreeraj CR, Abhilash KR, Purvaja R, Ramesh R (2019) Marine snakes of Indian coasts: historical resume, systematic checklist, toxinology, status, and identification key. Journal of Threatened Taxa 11 (1): 13132-13150. https://doi.org/10.11609/jott.3981.11.1.13132-13150

Haidar IKA, Romon BB, Chowdhury MAW (2020) First record of the Condanarous sand snake (Psammophis condanarus) (Reptilia: Squamata: Lamprophiidae) from Bangladesh. Journal of AsiaPacific Biodiversity 13 (4): 716-719. https://doi.org/10.1016/j.japb. 2020.08.013

Hasan MK, Khan MMH, Feeroz MM (2014) Amphibians and reptiles of Bangladesh - a field guide. Arannayk Foundation, Dhaka, Bangladesh, $191 \mathrm{pp}$.

Heatwole H (1999) Sea snakes (2nd edition). Krieger Publishing, Malabar, USA, 148 pp.

Husain KZ (1977) Bangladesher banayanjontu shampad o tar sangrakshan (in Bengali). Bangla Academy Bijnan Patrica 3 (3): 1-11.

IUCN Bangladesh (2015) Red List of Bangladesh, volume 4: reptiles and amphibians. International Union for Conservation of Nature, Bangladesh Country Office, Dhaka, Bangladesh, 320 pp.

Kabir SMH, Ahmad M, Ahmed ATA, Rahman AKA, Ahmad ZU, Begum ZNT, Hassan MA, Khondker M (2009) Encyclopedia of flora and fauna of Bangladesh. Vol. 25. Asiatic Society of Bangladesh, Dhaka, Bangladesh, 204 pp.

Khan MAR (1982) Wildlife of Bangladesh-a checklist. Dhaka University Press, Dhaka, Bangladesh, 174 pp.

Khan MAR (1987) Bangladesher banaya prani (wildlife of Bangladesh). Vol. 1. Bangla Academy, Dhaka, Bangladesh, 169 pp. [in Bengali]

Khan MAR (1992) Bangladesher shap. Bangla Academy, Dhaka, Bangladesh, 227 pp. [in Bengali]

Khan MAR (2015) Wildlife of Bangladesh: checklist-cum-guide. MJ Alam, Chayabithi, Dhaka, Bangladesh, 568 pp.

Khan MMH (2008) Protected areas of Bangladesh—a guide to wildlife. Nishorgo Program, Bangladesh Forest Department, Dhaka, Bangladesh, $304 \mathrm{pp}$.

Khan MMH (2018) Photographic guide to the wildlife of Bangladesh. Arannayk Foundation, Dhaka, Bangladesh, 488 pp.
Mahony S, Reza AHMA (2008) A herpetofaunal collection from the Chittagong Hill Tracts, Bangladesh, with two new species records for the country. Hamadryad 32 (1): 34-35.

Mahony S, Hasan MK, Kabir MM, Ahemd M, Hossain MK (2009) A catalogue of amphibians and reptiles in the collection of Jahangirnagar University, Dhaka, Bangladesh. Hamadryad 34 (1): 80-94.

Milton D, Fry G, Dell Q (2009) Reducing impacts of trawling on protected sea snakes: by-catch reduction devices improve escapement and survival. Marine and Freshwater Research 60: 824-832. https://doi.org/10.1071/MF08221

Montaquim MA, Sarkar AH, Khan MAR, Husain KZ (1980) List of the snakes of Bangladesh. Bangladesh Journal of Zoology 8 (2): $127-129$.

Murphy JC (2012) Marine invasions by non-sea snakes, with thoughts on terrestrial-aquatic-marine transitions. Integrative and Comparative Biology 52 (2): 217-226. https://doi.org/10.1093/icb/ics060

Nankivell JH, Goiran C, Hourston M, Shine R, Rasmussen AR, Thomson VA, Sanders KL (2020) A new species of turtleheaded sea Snake (Emydocephalus: Elapidae) endemic to Western Australia. Zootaxa 4758 (1): 141-156. https://doi.org/10.11646/ zootaxa.4758.1.6

Rasmussen AR (1987) Persian Gulf sea snake Hydrophis lapemoides (Gray): new record from Phuket Islands, Andaman Sea and the southern part of Straits of Mallaca. Siam Society Natural History Bulletin 35: 57-58.

Rasmussen AR (1993) The status of the Persian Gulf Sea Snake $H y$ drophis lapemoides (Serpentes, Hydrophiidae). Bulletin of the British Museum of Natural History (Zoology Series) 59 (2): $97-$ 105.

Rasmussen AR (1997) Systematics of sea snakes (a critical review). Proceedings of the Zoological Society of London 70: 1530.

Rasmussen A, Sanders K, Lobo A (2010) Hydrophis lapemoides (errata version published in 2016). The IUCN Red List of Threatened Species 2010: e.T176741A98102816. Accessed on: 2021-01-28. https://doi.org/10.2305/iucn.uk.2010-4.rlts.t176741a7294992.en

Rezaie-Atagholipour M, Ghezellou P, Hesni MA, Dakhteh SMH, Ahmadian H, Vidal N (2016) Sea snakes (Elapidae, Hydrophiinae) in their westernmost extent: an updated and illustrated checklist and key to the species in the Persian Gulf and Gulf of Oman. ZooKeys 622: 129-164. https://doi.org/10.3897/zookeys.622.9939

Romon BB, Chowdhury MAW, Haidar IKA (in press) First record of the Coral Red Kukri Snake Oligodon kheriensis) (Reptilia: Squamata: Colubridae) from Bangladesh. Journal of Asia-Pacific Biodiversity. https://doi.org/10.1016/j.japb.2021.04.001

Somaweera R, Somaweera N (2009) An overview of Sri Lankan sea snakes with an annotated checklist and a field key. Taprobanica 1 (1): 43-54.

Sanders KL, Lee MS, Leys R, Foster R, Scott Keogh J (2008) Molecular phylogeny and divergence dates for Australasian elapids and sea snakes (Hydrophiinae): evidence from seven genes for rapid evolutionary radiations. Journal of Evolutionary Biology 21 (3): 682-695. https://doi.org/10.1111/j.1420-9101.2008.01525.x

Sarker MAR, Sanders KL, Ukuwela KD, Jamam MF (2017) Sea snakes of Bangladesh: a preliminary survey of Cox's Bazar District with notes on diet, reproduction, and conservation status. Herpetological Conservation and Biology 12 (2): 384-393.

Sarker MSU (2013) Threatened herpetofauna of Bangladesh: present and past status and conservation issues. Bulletin de la Société Herpétologique de France 145-146: 29-48.

Sarker MSU, Sarker NJ (1985) Reptiles of Bangladesh (with their status, distribution and habitat). Tiger Paper 12 (2): 6-12.

Sarker MSU, Sarker NJ (1988) Wildlife of Bangladesh (a systematic list with status, distribution and habitat). The Rico Printers, Dhaka, Bangladesh, 69 pp.

Smith MA (1943) The Fauna of British India, Ceylon and Burma including the whole of the Indo-Chinese sub-region. Reptilia and Amphibia. Vol 3. Serpentes. Taylor and Francis, London, UK, 583 pp. 
Uetz P, Hallermann J (2021) The reptile database. http://www.reptiledatabase.org. Accessed on: 2021-4-24.

Ukuwela KD, Sanders KL, Fry BG (2012). Hydrophis donaldi (Elapidae, Hydrophiinae), a highly distinctive new species of sea snake from northern Australia. Zootaxa 3201 (1): 45-57. https://doi. org/10.11646/zootaxa.3201.1.3

Volsøe H (1939) The sea snakes of the Iranian Gulf and the Gulf of Oman, with a summary of the biology of the sea snakes. In: Jessen K, Spank R (Eds.) Danish Scientific Investigations in Iran, Part I. Copenhagen, Denmark, 9-45.

Wallach V, Williams KL, Boundy J (2014) Snakes of the world: a cat- alogue of living and extinct species. Taylor and Francis Group, Boca Raton, USA, 1227 pp.

Ward TM (2000) Factors affecting the catch rates and relative abundance of sea snakes in the by-catch of trawlers targeting tiger and endeavour prawns on the northern Australian continental shelf. Marine and Freshwater Research 51 (2): 155-164. https://doi. org/10.1071/mf98134

Wassenberg TJ, Milton DA, Burridge CY (2001) Survival rates of sea snakes caught by demersal trawlers in northern and eastern Australia. Biological Conservation 100: 271-280. https://doi. org/10.1016/S0006-3207(01)00031-3 